IDEA - Studia nad strukturą i rozwojem pojęć filozoficznych $\mathrm{XXVIII/2}$

\title{
SŁAWOMIR RAUBE
}

(Białystok)

\section{RELIGIA NA GRANICY MITU}

Zjawiska religijne obejmują bardzo szerokie spektrum wydarzeń duchowych, rytualnych, struktur instytucjonalnych i dogmatycznych przeświadczeń na temat określonej mechaniki świata rządzonego przez siły nadprzyrodzone. Ale zarazem religie szkicują portret człowieka, uwikłanego w sieć zależności ukontekstualizowanych przyrodą i sferą sacrum; bez względu na poziom rozwoju religii. Nawet najbardziej pierwotne formy myśli religijnej i mitycznej (a w najdawniejszych formach trudno je wyraźnie oddzielić $\left.{ }^{1}\right)$ nie unikają motywu relacji między człowiekiem a sferą tego, co nierozpoznane, co jawi się jako nieprzeniknione dla ludzkiej świadomości. Tym bardziej dotyczy to religii dojrzalszych, wyżej zorganizowanych, bardziej świadomych swojej problematyki. Ale zawsze w najróżnorodniejszych postaciach religii składnik antropologiczny odgrywa rolę centralną. Inaczej mówiąc, religia jest całym rejestrem odpowiedzi nie wprost

${ }^{1}$ Zob. Ernst Cassirer, Mit państwa, przeł. Anna Staniewska, Warszawa 2006, s. 40, 50. Cassirer próbując ustalić „systematykę ducha ludzkiego”, czyli określić różne rodzaje naszych duchowych interpretacji świata, przestrzega przed zbyt rygorystycznym i schematycznym ich oddzieleniem, jakkolwiek powinno się zakładać ich ogólną wzajemną odmienność. Wyjaśnia ten punkt widzenia tak oto: „Teoretyczna, a w szczególności filozoficzna myśl nie może nigdy z takiego wytyczenia granic zrezygnować: musi ona wszakże przy tym mieć świadomość, iż owe granice, które ustanawia myślenie, nie mogą zastygnąć w stałe bariery - że muszą one pozostać granicami ruchomymi, aby pomieścić w sobie pełnię i ruch zjawisk”; Ernst Cassirer, Przestrzeń mityczna, estetyczna i teoretyczna, [w:] tenże, Symbol i jezyk, przeł. Bolesław Andrzejewski, Poznań 1995, s. 125. 
(tylko czasami wprost), na pytanie, jakie jest nasze miejsce w ogromie rzeczywistości; w kontekście sił boskich i zjawisk przyrody.

Ernst Cassirer, którego analizy są punktem centralnym niniejszego tekstu, utrzymuje, że religijna interpretacja świata odegrała niebywale ważną rolę nie tylko $\mathrm{w}$ wymiarze rozwoju kosmologii, ale przede wszystkim w procesie ukonstytuowania się moralnej aksjologii. Bez religijnej interpretacji, która podlegała w toku dziejów licznym procesom ewolucyjnych zmian, nie mielibyśmy wykrystalizowanej moralności, która również przechodziła różnorodne historyczne transformacje i znajdowała odmienne legitymizacje, niemniej stanowi ona od dawna trwały azymut w naszej działalności kulturotwórczej. Przekonanie Cassirera może przypominać poglądy Durkheima na religię, jednak argumentacja przez niego zastosowana jest inna, a stanowisko co do zasadności merytorycznej (prawdziwościowej) religii świadomie niedopowiedziane, w przeciwieństwie do francuskiego socjologa.

Cassirerowi w żadnej mierze nie chodzi zatem o analizowanie religii czy mitu od strony prawdziwości ich wyobrażeń w stosunku do rzeczywistości. Chodzi tu bowiem o ukazanie topografii czy „kkładni” wyobrażeń mitycznych i religijnych, czyli o ich formę interpretacji świata, a nie o ich treść konfrontowaną z wymogami metodologicznymi i faktycznymi danymi, jakich oczekujemy od myśli filozoficznej czy naukowej. Mit czy religia posiadają swoją logikę, jest ona jednak - co oczywiste - odmienna od logiki nauk empirycznych. Chodzi tu o specyfikę f o r m y rozumienia świata, ale nie o jej prawdę. Cassirer pokazuje, że głównymi liniami regulacyjnymi myślenia mitycznego i religijnego (w jego wczesnych fazach rozwojowych) jest postrzeganie rzeczywistości jako jednorodnego środowiska, w którym wszelkie formy życia się ze sobą konfrontują i zarazem przenikają; to jest ta tak często przywoływana przez filozofa solidarność życia, pojęta jako wspólnota jestestw rządzona jednym prawem. Pisze bowiem tak: „W odczuciu mitycznym i religijnym przyroda staje się jedną wielką społecznością, społecznością życia. W tej społeczności człowiek nie otrzymuje specjalnej pozycji. Jest jej częścią, ale pod żadnym względem nie stoi wyżej niż

${ }^{2}$ Zob. Przemysław Parszutowicz, Fenomenologia form symbolicznych. Podstawowe pojęcia i inspiracje „późnej” filozofii Ernsta Cassirera, Warszawa 2014, s. 112. 
wszyscy inni jej członkowie. Życie ma tę samą godność religijną w najniższych i w najwyższych formach" ${ }^{3}$. Z tego przeświadczenia wyrastało mityczne przekonanie (i pragnienie), że śmierć nie jest aktem ostatecznym, że nie kończy definitywnie istnienia, a tylko zmienia postać. Pod tym względem mit i religia są różnymi reakcjami na problem przemijania, przy czym nie jest to różnica jakościowa, lecz narracyjna: mit formułuje opowieść, by tak rzec, poetycką, religia odwołuje się do jakiejś formy racjonalności. Ale w obu tych interpretacjach świata afirmacja życia jest podkreślana w sposób bezdyskusyjny. „W pewnym sensie pisze Cassirer - całą myśl mityczną można zinterpretować jako stałe i uparte negowanie zjawiska śmierci. Mocą przeświadczenia o nieprzerwanej jedności i ciągłości życia myśl mityczna musiała to zjawisko usunąć. Religia pierwotna jest może najsilniejszą i najbardziej energiczną afirmacją życia, jaką spotykamy w kulturze" ${ }^{4}$. Obie te formy rozumienia świata odwołują się bardziej do uczucia niż do logiki rozumu, stąd ich, jak to nazywa Cassirer, pogląd syntetyczny, nie analityczny, że nie ma miejsca w rzeczywistości na odrębne klasy, rodzaje, gatunki, swego rodzaju odseparowane regiony życia, wszystko bowiem jest ciągłą całością, zatem regułą fundamentalną jest prawo metamorfozy, oznaczające, że wszystko może się nagle przemienić we wszystko ${ }^{5}$. Spojrzenie mityczne i religijne (w religiach pierwotnych) jest sympatyczne, co oznacza pogląd, że wszelkie istoty żywe postrzega się jako przynależące na równych prawach do tego samego królestwa istnienia.

To właśnie uczucie, że rzeczywistość jest pomimo pozornych różnic fundamentalnie jednorodna, nadaje mitowi i religii pierwotnej spójność, swego ro-

${ }^{3}$ Ernst Cassirer, Esej o cztowieku. Wstęp do filozofii kultury, przeł. Anna Staniewska, Warszawa 1971, s. 153.

${ }^{4}$ Esej, $154-155$.

${ }^{5}$ Zob. tamże, s. 152. Tę dynamiczność i dialektyczność mitycznego obrazu świata Cassirer opisuje w następujący sposób: „Każdy twór może przemienić się w inny, wszystko może powstać ze wszystkiego. Postać rzeczy może się zmienić w mgnieniu oka, bowiem nie jest zbudowana z trwałych własności. «Własności» $\mathrm{i}$ «właściwości» są momentami, z którymi obserwacja empiryczna zapoznaje nas tylko, o ile te same określenia i stosunki stwierdzane są wciąż na nowo, przez cały czas. Mit nie zna takiej jednorodności i równokształtności. Dla niego w każdej chwili świat może otrzymać inny wygląd, ponieważ tym, co określa ów wygląd jest afekt”; E. Cassirer, Logika nauk o kulturze. Pięć studióww, przeł. Przemysław Parszutowicz, Kęty 2011, s. 64-65. 
dzaju wewnętrzną logikę, dzięki której tworzą one koherentne symboliczne interpretacje świata, bynajmniej nie sprzeciwiające się racjonalności pojętej najszerzej. I to ma na myśli Cassirer mówiąc, że są one formami symbolicznymi na równych zasadach jak język czy nauka, są bowiem symbolicznymi syntezami doświadczenia, choć odmiennymi od syntez naukowych czy tych, które stanowią podstawową strukturę języka odpowiadającą logice myślenia zdroworozsądkowego ${ }^{6}$. Oznacza to, że religia w swoich najstarszych postaciach (tym bardziej późniejsze formy myśli religijnej) nie jest przypadkowym zlepkiem najdziwaczniejszych opowieści odzwierciedlających prymitywny stan ducha naszych przodków; nawet religia pierwotna ujawnia swoje racje i zasady. Religie totemiczne miały swoją własną regułę porządkowania świata, egzorcyzmowania niebezpieczeństw poprzez szczegółowe przepisy ich stygmatyzowania. Być może nie posiadano wtedy wyjaśnień dla tak szkicowanego świata, ale jak pisze Cassirer rytuał poprzedza dogmat, to znaczy treść religijna pojawia się na długo po ukonstytuowaniu się religijnego obrzędu, chociaż należy pamiętać, że z rytuałem wiążą się określone wyobrażenia życia ${ }^{7}$. To, co łączy różnorodne opowieści mityczne i różnorodne religie, nie jest wspólnotą konkretnych przeświadczeń, treści dogmatycznych i teologicznych, a nawet wspólnych ideałów etycznych; wszystkie one składają się w ostatecznym bilansie na ogromną masę rozbieżnych elementów; jednak wspólna jest im zasada porządkowania danych doświadczanego świata - „działanie symboliczne jako takie”, które „pozostaje to samo: una est re-

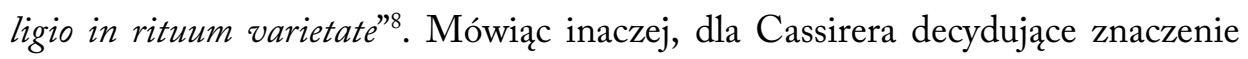
w jego analizach ma nie treść poszczególnych mitów i religii, ale ich forma, forma wyobraźni mitycznej i myślenia religijnego.

Rozpowszechnione przekonanie, że strach jest źródłem religii (primus in orbe deos fecit timor), nie ułatwia zrozumienia genezy tego zjawiska, albowiem to przekonanie zakłada, że religia wyrasta z biernej obrony życia ludzkiego i jest prostą reakcją na konstatację kruchości egzystencji. Cassirer twierdzi, że przy ta-

${ }^{6}$ Zob. Hanna Buczyńska, Cassirer, Warszawa 1963, s. 83.

7 Zob. Sussanne K. Langer, Nowy sens filozofii. Rozważania o symbolach myśli, obrzędu i sztuki, przeł. Alina Hanna Bogucka, Warszawa 1976, s. 246.

${ }^{8}$ E. Cassirer, Esej o cztowieku, wyd. cyt., s. 139. 
kim założeniu nie będziemy w stanie ująć istoty religii, w jej obrębie bowiem zawarty jest składnik optymizmu i wiary w samego siebie jako człowieka, co wykracza poza zakres wyznaczony pojęciem strachu. Pisze: „Wydaje się jednak, że nawet w najdawniejszych i najniższych stadiach cywilizacji człowiek znajdował nową siłę, dzięki której mógł się opierać i odsuwać od siebie lęk przed śmiercią. Tym, co człowiek przeciwstawiał śmierci, była ufność, jaką pokładał w solidarności i w nieprzerwanej niezniszczalnej jedności życia" ${ }^{\circ}$. Już raczej bliższa prawdy jest hipoteza Herberta Spencera, mówiąca o kulcie przodków jako pierwotnej inspiracji zjawiska religii, bo to ten kult właśnie wydaje się występować we wszelkich pierwotnych formach religii, organizując ich przestrzeń rytualną i symboliczną.

Wydaje się, że dla Cassirera momentem przełomowym na drodze wykrystalizowania religii i oddzielenia się od mitycznych wyobrażeń jest odkrycie przez człowieka wiary w samego siebie; odnalezienie przekonania, że my sami mamy jakąś wartość. A do tego doszło na długiej ewolucyjnej drodze myśli religijnej, poprzedzonej rozwojem magii i mitu, gdy religia weszła w fazę antropomorfizacji bogów. Ten podkreślany przez Cassirer aspekt ewolucyjnego przechodzenia myśli religijnej od stadiów pierwotnych do wyżej zorganizowanych jest polemiką z koncepcją Henri'ego Bergsona o dwóch typach religii - „statycznej” i „dynamicznej” ${ }^{10}$. Cassirer utrzymuje, że refleksja religijna (zatem myśl pozostająca $\mathrm{w}$ zakresie szeroko rozumianej racjonalności) nie rozwijała się, by tak rzec, „skokowo”, ale poprzez stopniową zmianę transformacyjną zmierzającą od mitu i magii, poprzez antropomorfizację greckiej religii olimpijskiej, do religii etycznych. O stopniowym przechodzeniu od mitu do religii pisze Cassirer tak oto: „Pod tym względem nie ma zasadniczej różnicy pomiędzy myślą mityczną a religijną. Obie wywodzą się z tych samych podstawowych zjawisk życia ludz-

\footnotetext{
${ }^{9}$ Tamże, s. 157.

${ }^{10}$ Bergson utrzymuje, że religie przybierają w toku swojego rozwoju dwie odmienne postacie: kapłańską (statyczną) i proroczą (dynamiczną); pierwsza jest zinstytucjonalizowana, sformalizowana, druga przeciwnie - jest skutkiem nowych wizji proroków, jest niejako religią in statu nascendii, religią w stanie wrzenia, poszukującą swojej nowej postaci; zob. Henri Bergson, Dwa źródła moralności i religii, przeł. Piotr Kostyło, Krzysztof Skorulski, Kraków 2007 (rozdziały: Religia statyczna i Religia dynamiczna).
} 
kiego. Nie potrafimy w rozwoju kultury ustalić momentu, w którym kończy się mit, a zaczyna religia. Religia jest w całym przebiegu swych dziejów przesycona elementami mitycznymi i nierozerwalnie $z$ nimi związana. $Z$ drugiej strony mit, nawet $\mathrm{w}$ swych formach najbardziej prymitywnych i rudymentarnych, kryje $\mathrm{w}$ sobie motywy zapowiadające $\mathrm{w}$ pewnym sensie późniejsze ideały religijne wyższego rzędu. Od samego początku mit jest potencjalną religią. $Z$ jednego stadium do drugiego przechodzi się stopniowo, nie zaś w drodze gwałtownego zwrotu myśli i przewrotu uczuciowego"11.

Przejście od mitu do religii dokonywało się na różnych poziomach, a i tak ostatecznie do całkowitego oddzielenia nigdy nie doszło: pewne elementy mitycznej interpretacji świata są przecież $\mathrm{w}$ religii stale obecne ${ }^{12}$. Cassirer jest przekonany, że pierwotnym impulsem tworzenia narracji mitycznych był najdawniejszy pogląd o solidarności życia, $\mathrm{z}$ którego wyrasta mityczne prawo metamorfozy: wszystkie istoty uczestniczą we wspólnocie istnienia, wszystkie istoty podlegają tym samym mechanizmom, które określają rytm życia, ale z tej wspólnoty istnienia wynika przekonanie, że nic nie ginie bezpowrotnie, a jedynie dokonuje się wraz ze śmiercią zmiana formy istnienia. To jest ta „sympatia wszechrzeczy”, którą spotykamy w większości systemów mitycznych. Ale religia nie negując tego przeświadczenia poddaje go transformacji, zmienia jego kierunek semantyczny i imaginacyjny - pozostawiając w nim przekonanie o byciu częścią wszechogarniającej całości istnienia, wykrystalizowuje poczucie odrębności indywidualnej, wagi własnej niepowtarzalności. $W$ ten sposób myśl religijna tworzy wewnętrzną antynomię, która odtąd towarzyszyć będzie religii nieustannie; chodzi o napięcie między uniwersalnością a indywidualnością, między skończonością

${ }^{11}$ E. Cassirer. Esej..., wyd. cyt., s. 160. Aktywność mitotwórcza i umiejętność posługiwania się symbolami, wyrażone w słynnej definicji Cassirerowskiej jako animal symbolicum stanowią podstawowe odmienności człowieka od innych istot żywych; jednak ta ludzka skłonność do konstruowania mitów wydaje się także przynależeć do natury człowieka, w przeciwnym razie nie określatby niemiecki filozof człowieka jako „a mythical animal” - istoty mitotwórczej; zob. E. Cassirer, The Technique of our Modern Political Myths, [w:] Symbol, Myth, and Culture. Essays and Lectures of Ernst Cassirer 1935-1945, ed. Donald Phillip Verene, New Haven and London 1979, s. 246.

${ }^{12}$ Podobne trudności wskazuje Cassirer w kwestii relacji magii i religii, stwierdzając, że ten związek jest kontrowersyjny i niejasny, ponieważ porównanie religii do magii, deprecjonuje religię; jednak wyraźne oddzielenie tych zjawisk okazuje się niezwykle trudne. 
(własnego istnienia) a nieśmiertelnością (pragnieniem kontynuacji własnego życia i całego rodzaju ludzkiego). Można powiedzieć, że zdaniem Cassirera myśl religijna na swoich wyższych poziomach rozwoju odkrywa indywidualność osoby ludzkiej ${ }^{13}$. Ale to odkrycie miało konsekwencje w religijnych wyobrażeniach i projekcjach, albowiem człowiek zaczął postrzegać siły boskie jako obdarzone cechami ludzkimi. „Aby ten cel osiagnąć - pisze Cassirer - myśl religijna musiała jednak przebyć długą drogę. Zanim człowiek potrafił nadać swym bogom określoną indywidualność, musiał najpierw odkryć w swoim własnym istnieniu i w swym życiu społecznym nową zasadę dyferencjacji. Zasadę tę znalazł nie w myśli abstrakcyjnej, lecz w pracy. Nową erę myśli religijnej zapoczątkował $\mathrm{w}$ istocie podzial pracy"14.

Podział pracy i wynalezienie pieniądza zmieniły, jak sądził także John Locke, stosunki społeczne. Ale czy ta zmiana znalazła odzwierciedlenie w świadomości społecznej i dominującym imaginarium? Cassirer sądzi, że tak. Podział pracy był mechanizmem zindywidualizowania jednostki ludzkiej, ale pamiętać należy, że dokonał się w epoce przedindustrialnej, dalekiej od typowych procesów umasowienia społeczeństwa i zinstrumentalizowania samej pracy, które pojawiły się dopiero w epoce nowożytnej. Był ten najdawniejszy podział pracy procesem dowartościowania istoty ludzkiej. Zatem jedną z podstawowych tez Cassirera $\mathrm{w}$ zakresie jego analiz religii jest przekonanie, że religijna interpretacja świata podlegała ewolucji w kontekście przemian społecznych. Ewolucja ta w swoich formach najprostszych wychodziła od dostrzegania w przyrodzie sił i mocy tajemnych i nadprzyrodzonych, ale pojęcia, które do nich stosowała, były jeszcze nieokreślone (np. mana); te najpierwotniejsze formy religijności są w istocie nieoddzielalne od mitu; można powiedzieć, że w najstarszych stadiach ludzkości mit i religia żyją w symbiozie. Zmiana religijnego postrzegania świata nastąpiła, gdy pojawili się w kulturze rzymskiej tak zwani bogowie funkcjonalni, jak ich nazywa Cassirer; byli bardziej wykrystalizowani niż siły nadprzyrodzone

${ }^{13}$ Inni badacze, pośród których wypada wymienić Karla Rajmunda Poppera, utrzymywali, że odkrywcą indywidualności i niepowtarzalności jednostki ludzkiej była jednak grecka filozofia. Zob. Jerzy Szacki, Historia myśli socjologicznej, Część pierwsza, Warszawa 1983, s. 31-32.

${ }^{14}$ E. Cassirer, Esej..., wyd. cyt., s. 173. 
wcześniejszej umysłowości mitycznej. Pisze o nich Cassirer tak oto: „Są to istoty konkretne, ale konkretne w swych działaniach, nie zaś w swym istnieniu czy wyglądzie. Nie mają więc imion własnych, jak Zeus, Hera, Apollo, lecz imiona przymiotnikowe, charakteryzujące ich szczególną funkcję czy działalność” ${ }^{\prime 5}$. To są bogowie lokalni, przypisywani poszczególnym czynnościom praktycznym, którym mają patronować i im sprzyjać w ramach swojej życzliwej opatrzności; pojawiają się wyłącznie w formie kolektywnej, występując zawsze w liczbie mnogiej (di manes - dobre bóstwa). Oznacza to, że są jeszcze nie do końca uformowani, że są jeszcze zaledwie wyczuwani, a nie odkryci i ukonkretnieni w odrębnych obrzędach rytualnych. Pod wpływem kultury greckiej kształtują się ich coraz bardziej zindywidualizowane właściwości. Pojawienie się greckich bogów olimpijskich, zdaniem Cassirera, zmienia zwrotnice na torze rozwoju myśli religijnej. To jest wstęp do koncepcji monoteistycznych religii, w tym przede wszystkim aspekcie, że greccy bogowie zyskują cechy ludzkie, że stają się analogonami ludzi, choć są oni ujmowani w stopniu doskonałości absolutnych, niedostępnych dla jednostek ludzkich - co w późniejszej epoce rozwoju myśli religijnej znajdowało kontynuacje, jak choćby w średniowiecznym ujęciu eminencji Bożych własności (np. św. Tomasz z Akwinu).

Religijność starożytności greckiej staje się punktem zwrotnym: spersonifikowane istoty boskie Homera i Hezjoda są poddane transformacji ze strony Heraklita, Anaksagorasa, a także poetów epickich Ajschylosa i Eurypidesa; bogowie olimpijscy wyposażeni są już w osobowości, posiadają imiona własne i wyrażają określone ideały moralne. Zdaniem Cassirera było to nieodzowne stadium prowadzące do kolejnej ewolucyjnej fazy rozwoju religii - do monoteizmu. Inaczej mówiąc, bez greckiej personifikacji sił boskich, bez antropomorfizacji, nie byłoby religii monoteistycznych. Ich warunkiem był podbój olimpijski. „Po tym podboju - pisze Cassirer - człowiek zaczął pojmować przyrodę i swoje miejsce w przyrodzie w sposób odmienny. Ogólne poczucie solidarności życia ustąpiło przed nowym i silniejszym motywem - specyficznym poczuciem indywidualności człowieka. Znikło już naturalne pokrewieństwo, poczucie związku, które łą-

15 Tamże, s. 173. 
czyło człowieka z roślinami i zwierzętami. Człowiek zaczął widzieć własną osobowość w nowym świetle, odzwierciedloną w bogach osobowych"16. Przejście do religii monoteistycznych, które na pierwszy plan wysuwały problematykę dobra i zła, pozwoliło unieważnić negatywność systemu tabu, złożonego z szczegółowego zestawu zakazu i napomnień. Religie monoteistyczne na pierwszy plan wysunęly ideały etyczne i aprobatywne uczucia; strach został niejako opanowany, w tym sensie, że Bóg, skupiający wszelkie moce kosmiczne został umiejscowiony w sferze sacrum, z z którym ludzkość zawarła przymierze, rodzaj transakcji wymiennej: za obrzędowość manifestującą pokorę wobec boskości zyskujemy gwarancję bezpieczeństwa. Tak oto człowiek staje się podmiotem, autonomiczną jednostką zdolną wejść w relacje z najwyższą siłą stwórczą.

Nowa postać religii, która wyewoluowała z fazy politeistycznej, stanowiła przekroczenie mitologii i pierwotnych religii, konstytuowała bowiem motywy moralne, prawie nieobecne $\mathrm{w}$ interpretacji mitycznej i pierwotnym rozumieniu religijnym. „W wielkich religiach monoteistycznych - pisze Cassirer - spotykamy się z całkiem odmiennym aspektem boskości. Religie te są wynikiem sił moralnych - koncentrują się na jednym punkcie, na problemie dobra i zła" ${ }^{17}$.

Pierwszą wielką religią etyczną był zdaniem niemieckiego filozofa zoroastryzm, w którym niepodzielną siłę moralną zyskuje Ahura Mazda, ucieleśnienie osobowej woli moralnej. Religie tej nowej fazy ewolucyjnej nie porzucają radykalnie wszystkich motywów i wyobrażeń mitologii i religii wcześniejszych stadiów. Niektóre składniki poprzednich interpretacji świata są w nich obecne, ale podlegają transformacji. Nie zanika na przykład fundamentalnie ważna dla mitu i magii zasada związku sympatycznego między człowiekiem a przyrodą, jednak ten związek zyskuje w religiach monoteistycznych inny sens, nie jak dawniej - emocjonalny, a racjonalny. Pisze Cassirer: „Jeśli przyroda zawiera w sobie element boski, to przejawia się on nie w bujności i bogactwie jej życia, lecz w prostocie panującego w niej porządku, z którego bierze początek wszelkie życie. Pojmowana jest jako sfera prawa i praworządności. I ten jeden rys świad-

\footnotetext{
16 Tamże, s. $164-165$.

17 Tamże, s. 177.
} 
czy o jej boskim pochodzeniu"18. W ten sposób mityczna solidarność życia została przekształcona przez judaizm najpierw, a później przez chrześcijaństwo w zasadę uniwersalnej sympatii etycznej. Osią tych nowych zjawisk religijnych nie była już dystynkcja nieczyste-czyste, uświęcone-skalane, ale moralneniemoralne. I były to dystynkcje nie konkretne, fizyczne, jak w systemach tabu, a rozróżnienia wymagające refleksji. To pociągało za sobą szereg konsekwencji, pośród których najistotniejsze były kwestie społecznej odpowiedzialności; wszak moralność wymaga zindywidualizowania w procesie podejmowania decyzji, osobistego przyjęcia na siebie skutków wyboru, co zdaniem Cassirera jest warunkiem cywilizacji. A równie istotnym skutkiem tej przemiany, i jej warunkiem, było wykrystalizowanie ideału wolności: człowiek moralnie odpowiedzialny za swoje wybory i czyny musi być wolny. W religiach wyższego rzędu, w religiach etycznych człowiek znajduje drogę do Stwórcy i do tego, co jest punktem docelowym: zbawienie i nieśmiertelność można osiągnąć wyłącznie na drodze moralnej prawości; a droga ta wiedzie poprzez świat przyrody, adaptacja do której staje się wyzwaniem etycznym, a nade wszystko przez relacje z innymi ludźmi ${ }^{19}$. Problem dobra staje się w tej fazie rozwoju religii elementem decydującym; jak pisze Cassirer, „Świat stał się wielkim dramatem moralnym, w którym i człowiek, i przyroda muszą odegrać swoje role"20. Ale to przejście dokonało się na drodze żmudnej i długotrwałej przemiany ewolucyjnej, a nie w ramach skoku rewolucyjnego ${ }^{21}$.

Wszelako religie monoteistyczne zachowały pewne elementy faz wcześniejszych. Trudno się dziwić obecności w nich mistycyzmu; element tajemniczości, przeżywanie poza granicami rozumu obecności siły boskiej jest składnikiem wszystkich wielkich religii monoteistycznych. Wszystkie te religie posiadały wielkich reformatorów czy nauczycieli. Jednak Cassirer twierdzi (wbrew Bergsonowi), że ci wielcy reformatorzy religijni nie tworzyli nowych postaci re-

${ }^{18}$ Tamże, s. 178.

${ }^{19}$ „Tu bowiem, jedynie przez wolność, poprzez samodzielną decyzję człowiek może zetknąć się z bóstwem. Mocą takiej decyzji staje się sprzymierzeńcem bóstwa”; tamże, s. 179.

${ }^{20}$ Tamże, s. 178.

${ }^{21}$ „Ludzkość nie przechodzi od moralnego zobowiązania do religijnej wolności drogą jakiegoś rodzaju rewolucji”; tamże, s. 181. 
ligii, ale - transformując je - wzmacniali etyczne motywy wyznań, w których byli wychowani i których część stanowili; musieli ponadto przemawiać językiem zrozumiałym dla ludzi, a nie głosem boskości, który słyszeli jako prorocy. Rozszerzyli za to zakres swojego przesłania. „Prorocy - twierdzi Cassirer - przepowiadali nowe niebo i nową ziemię. Ale naprawdę nowa jest nie treść tej profetycznej religii, lecz jej wewnętrzna tendencja, jej znaczenie etyczne. Jednym z największym cudów, jakiego musiały dokonać wszystkie wyższe religie, było rozwinięcie i ukształtowanie swojego nowego charakteru oraz etycznej i religijnej interpretacji życia $\mathrm{z}$ nie obrobionego surowca najbardziej prymitywnych pojęć i najciemniejszych zabobonów"22.

Do tych wyższych religii Cassirer zalicza judaizm (religię proroków Izraela), zoroastryzm i chrześcijaństwo ${ }^{23}$. Właśnie w judaizmie widać wyraźnie to stopniowe przechodzenie od dawnych motywów czysto religijnych do nowego przesłania etycznego, do - nazywaną tak przez filozofa - religijnej zmiany znaczenia: „W księgach proroków Starego Testamentu odkrywamy zupełnie nowy kierunek myśli i uczucia. Ideał czystości oznacza tu coś całkiem odmiennego od wszystkich poprzednich pojęć mitycznych. Doszukiwanie się czystości lub nieczystości w przedmiocie, w rzeczy materialnej stało się niemożliwe. Nawet czyny ludzkie jako takie nie są już rozpatrywane jako czyste lub nieczyste. Jedyną czystością, która ma godność i znaczenie religijne, jest czystość serca”24. To przejście judaizmu od zmitologizowanej religii do religii etycznej było później - już w czasach współczesnych - uznawane przez nazistów jako jedna z największych zbrodni narodu żydowskiego ${ }^{25}$. I stanowiło przełom $w$ religijnej interpretacji świata, zapowiadając kolejną fazę - chrześcijańską.

Analizy Cassirera są interesujące i bez wątpienia inspirujące. Jednak ich słabsze strony wynikają z ograniczonego materiału empirycznego, na którym oparta jest jego refleksja o religii; obejmuje ona bowiem przede wszystkim prace

22 Tamże, s. 183.

${ }^{23}$ Zob. tamże, s. 190. Zastanawiający jest brak w tym wyszczególnieniu islamu.

${ }^{24}$ Esej, s. 188.

${ }^{25}$ Zob. E. Cassirer, Judaism and the Modern Political Myths, [w:] Symbol, Myth and Culture, wyd. cyt., s. 240. Na ten temat zob. także Sławomir Raube, Powracajacy mit: idea regresu w filozofii kultury Ernsta Cassirera, „Kultura i Wartości” 2(10), 2014. 
antropologów kulturowych, w znacznym stopniu z kręgu ewolucjonizmu klasycznego (choć obecny jest także funkcjonalizm Bronisława Malinowskiego), poddawane po pierwszej wojnie światowej krytyce przez przedstawicieli kolejnych szkół i nurtów antropologii. Rzecz jasna nie umniejsza to oryginalności myśli Cassirera; w zakresie oryginalnych pomysłów filozoficznych pozostaje on jednym z najwybitniejszych myślicieli XX wieku, jednakże jego argumentacja na temat myśli religijnej wydaje się w świetle dzisiejszej wiedzy (ale także tej z lat 30. i 40. XX wieku) nieco zbyt pochopnie uogólniona. Nadto źródła, na których Cassirer oparł swoją syntezę religijności greckiej, także zostały poddane wiarygodnej krytyce jako uproszczające stan rzeczy. Mimo tych wadliwości niejako przygodnych w istocie rzeczy sedno ujęć pozostaje niezmiennie zaciekawiające.

\title{
RELIGION ON THE BORDER OF THE MYTH
}

\author{
Summary
}

Cassirer thought that religion is one of the main fundamental rule of a human society and cultural order, mainly because it is able to guarantee moral laws being the main grounds of our civilization. But religion could not have been existed if it had not been preceded by mythical thinking. The myth is a real condition of religion. Religious interpretation is permeated by mythical metaphors, but the border between them is difficult to identify.

Key words: myth, religion, values, morality, anthropology, Cassirer

Słowa kluczowe: mit, religia, wartości, moralność, antropologia, Cassirer

\section{Bibliografia}

Henri Bergson, Dwa źródta moralności i religii, przeł. Piotr Kostyło, Krzysztof Skorulski, Kraków 2007.

Hanna Buczyńska, Cassirer, Warszawa 1963.

Ernst Cassirer, Esej o cztowieku. Wstęp do filozofii kultury, przeł. Anna Staniewska, Warszawa 1971. 
Ernst Cassirer, Judaism and the Modern Political Myths, w: Symbol, Myth and Culture. Essays and Lectures of Ernst Cassirer 1935-1945, ed. Donald Phillip Verene, New Haven and London 1979.

Ernst Cassirer, Logika nauk o kulturze. Pięć studiów, przeł. Przemysław Parszutowicz, Kęty 2011.

Ernst Cassirer, Mit państwa, przeł. Anna Staniewska, Warszawa 2006.

Ernst Cassirer, Przestrzeń mityczna, estetyczna i teoretyczna, w: tenże, Symbol i język, przeł. Bolesław Andrzejewski, Poznań 1995.

Ernst Cassirer, The Technique of our Modern Political Myths, w; Symbol, Myth, and Culture. Essays and Lectures of Ernst Cassirer 1935-1945, ed. Donald Phillip Verene, New Haven and London 1979.

Sussanne K. Langer, Nowy sens filozofii. Rozważania o symbolach myśli, obrzędu i sztuki, przeł. Alina Hanna Bogucka, Warszawa 1976.

Przemysław Parszutowicz, Fenomenologia form symbolicznych. Podstawowe pojęcia i inspiracje "późnej" filozofii Ernsta Cassirera, Warszawa 2014.

Sławomir Raube, Powracajacy mit: idea regresu w filozofii kultury Ernsta Cassirera, „Kultura i Wartości” 2(10), 2014.

Jerzy Szacki, Historia myśli socjologicznej, Część pierwsza, Warszawa 1983.

dr hab. Sławomir Raube

Zakład Wiedzy o Kulturze, Wydział Filologiczny Uniwersytetu w Białymstoku 